\title{
GENERÁCIÓS KÜLÖNBSÉGEK A MUNKAHELYEN
}

\author{
SZAKIRODALMI ÁTTEKINTÉS
}

A munkaerőpiacon jelenleg négy generáció (Baby boomer, X, Y és Z) van jelen, ami különleges kihívás elé állítja a szervezeteket. Mindezt jól mutatja az a tény, hogy az utóbbi évek vezetői és HR-szakmai konferenciáinak állandó témája a generációk munkahelyi viselkedési és értékrendi különbségei. A generáció kifejezést többféleképpen közelítik meg a témában kutatók. Létezik olyan nézőpont, mi szerint generációnak hívják a hasonló korú egyének csoportját. Más megközelítés szerint egy generációt alkot az a csoport, amely egyrészt egy bizonyos időintervallumban született, emellett nagyon hasonló történelmi, szociokulturális környezetben nőtt fel (Mannheim, 1952). A jelenlegi kutatás célja a témában eddig született eredmények feltérképezése, szintetizálása, különös tekintettel a generáció fogalmának alakulására.

Kulcsszavak: Millenium generáció, Baby boomer, Veteránok, generációs különbségek, generációs konfliktus a szervezetben

Ü zleti és HR-konferenciák, üzleti lapok és tréningek népszerü témája a generációk között fennálló különbségek okainak feltárása, az egyes generációk jellemzőinek meghatározása, tanácsok az ebből adódó konfliktusok megoldására. Jelen cikk célja a nemzetközi szakirodalom feltérképezése a generációk témakörében, a generáció fogalmának kialakulásától kezdve, a jelenleg használatban lévő definíciókon át a konkrét generációs különbségekig.

Jelenleg négy generáció van jelen a munkaerőpiacon, ami a következők eredménye: a munkával töltött évek száma folyamatosan nő, az egyénekre ható életesemények száma szintén nő az információs technológia fejlödésének köszönhetően, így az adott időintervallumban elkülönített generációk száma növekszik, tehát egy generáció időintervalluma folyamatosan csökken. Az elmúlt 20-30 év gyors fejlődése jelentős változást eredményezett az egyének életében. Akár évről évre változnak az eszközök, amiket használunk, az információ, amihez hozzáférünk stb. Mindezeknek köszönhetően a korban egymáshoz közel állók is gyakran nehezen értik meg egymást, mivel más müködést, kommunikációs formát, eszközöket tanultak meg használni. Többek között ez az oka annak, hogy a szervezetek problémaként élik meg a különböző generációk tagjainak egységes kezelését (Woodward et al., 2015; Fogg, 2009; Glass, 2007). HR-vezetők számolnak be arról mind Magyarországon, mind világszerte, hogy a generációs különbségekből adódó konfliktusos helyzetek nagyobb kihívás elé állítják a szervezeteket, mint az eddigiek (Soós, 2008). A szervezetek konfigurációjának laposodása ismert folyamat (Taródy, 2012), Zubány (2008) szerint ennek következtében a különböző generációk képviselői szorosan egymás mellett dolgoznak, ami ahhoz vezet, hogy a különbségek mind inkább kiélesednek.

Hasonló nehézségekröl árulkodik az a tendencia is, hogy számos tanácsadó és piackutató céget foglalkoztat a jelenség. Számos kutatást találunk az Y és $\mathrm{Z}$ generáció munkahelyi értékeiről, attitüdjéről, viselkedéséről e cégek által az elmúlt tíz évből (McKinsey, 2016; KPMG, 2007; E-Y, 2015; Deloitte, 2017; PwC, 2013). Emellett mind ma- gyar, mind nemzetközi kutatócégek végeznek felmérést az említett két generációt vizsgálva, számos aspektusból megközelítve. Ilyen kutatócég pl. a PEW Research Center, mely nagy hangsúlyt fektet a téma kutatására, föképp az Y (Millenium) generáció szokásait, viselkedését, attitüdjét vizsgálva. Az idősebb (X, Baby boomer) generációk szintén gyakran képezik fókuszát kutatásoknak, azonban a fiatalabb generációkra irányuló tanulmányok jóval gyakoribbak, aminek az lehet többek között az egyik oka, hogy az elsőszámú vezetők nagy része az idősebb generációkhoz tartozik. Magyarországon Törőcsik Mária Trend Inspiráció mühelye foglalkozik, fóként fogyasztói szokásaival a tárgyalt generációknak. Ezekben a kutatásokban többnyire nagy mintán vizsgálják a generációk munkahelyi jellemzőit, illetve iránymutatással szolgálnak a kezelésükre, motiválásukra stb.

Makroszinten nézve az elsődleges probléma, ami miatt sorra születnek ezek a kutatások, hogy a munkaerőpiacon jelentős munkaerőhiány van, aminek egyrészt demográfiai okai vannak, másrészt az Y generáció egyik tipikus attitüdjének tartott gyakori munkahelyváltás (,job hopping”) is hatással van a jelenségre. A szervezetek egy része nagy hangsúlyt fektet a munkaerő megtartására, elkötelezettségének növelésére, míg más szervezetek perspektívaváltásban gondolkoznak. Számos szervezet ugyanis ahelyett, hogy a generáció munkaértékeinek átalakítását venné célul, a megváltozott helyzethez való alkalmazkodásban gondolkozik. A PwC jelentéséből is kiderül, hogy hosszú távú víziójuk a projektalapú szervezeti formára való áttérés, aminek következtében a munkaerőt a képességeinek megfelelően éppen addig tartanák a szervezetnél, ameddig a projekt szempontjából szükséges. Köztes megoldásként látja számos szervezet az atipikus foglalkoztatási formák nagyobb arányú alkalmazását, válaszul a fiatalok kielégítőbb munka-magénélet egyensúly igényére. A végső cél természetesen a vállalat profitjának maximalizálása, aminek elengedhetetlen feltétele a megfelelő munkaerő jelenléte a vállalatnál. A változási folyamat természetes része az ellenállás a változással szemben. Nincs ez 
másképp a szervezetek esetében a mindig éppen újonnan megjelenő generációk kapcsán sem. Az újabb és újabb generációk változást hoznak a szervezetek életébe, amit más nagy horderejü változáshoz hasonlóan menedzselniük kell a szervezeteknek. Az Y generáció képviselői már közel tíz éve jelen vannak a munkaeröpiacon, így a szervezetek nagy része már túllépett az ellenállás fázisán és elköteleződött a megértés felé. Ennek eredményeképp születnek a fent említett kutatások, amik többnyire csak a tüneteket vizsgálják, azokra ajánlanak gyógyírt. Számos ilyen „kézikönyvvel” találkozhatunk, a várva várt megoldást azonban még nem hozták el ezek a kutatások, amire abból következtethetünk, hogy szinte 2-5 évente újra születnek.

A nemzetközi tudományos szakirodalomban számos olyan kutatást találunk, ami az okokra helyezi a hangsúlyt, a jelenségek gyökereit vizsgálja. A témát vizsgáló cikkek azonban eltérő mintán, eltérő, egymásnak ellentmondó eredményeket találtak. Jelen cikk célja a tudományos szakirodalom strukturált bemutatása a téma mélyebb megértése végett.

\section{A szakirodalom áttekintése}

A generációk, maga a generáció mint kutatási téma rendkívül népszerü (Soulez, 2011; Arnett et al., 2013; Joshi, 2011; Twenge, 2000; Kupperschmidt, 2000; Deal et al., 2010; Schuman - Scott, 1989; Kelan, 2014; Khera - Malik, 2014; Lyons - Kuron, 2014; Smola - Sutton, 2002) különösképp szervezeti kontextusban és számos kutatás irányul a különböző generációk viselkedésének, értékeinek, attitüdjének azonosítására. Kevés azonban a mélyebb okokat feszegető, feltáró, a jelenségre ható egyéb tényezőket (kultúra, lokáció, szervezeti jellemzők) is vizsgáló kutatás. Így a szakirodalom áttekintésekor gyakran leegyszerüsített, sztereotipizált eredményeket olvashatunk (Soulez, 2011).

A generációs kutatások túlnyomó része problémaként interpretálja a jelenlegi helyzetet, tehát egyrészt azt a jelenséget, hogy négy generáció van párhuzamosan jelen a szervezetek életében, másrészt egyfajta félelmetes, negatív jövőképet festenek le az újonnan megjelenő (Y és Z) generációk jellemzőiről, társadalmi szerepükről. A szerzők elenyésző része fektet hangsúlyt az új generációk erősségeire, illetve az ezekre épülő esetleges pozitív változásokra, amit előidézhetnek. Arnett et al. (2013) felhívja rá a figyelmet, hogy ez a tendencia veszélyes lehet, mivel a szülőknek és vezetőknek adnak át egyfajta értelmezési szemüveget, ami később önbeteljesítő jóslatként funkcionálhat.

\section{A generáció fogalmának meghatározása}

Több tudományterület is vizsgálja a generációk témakörét, leggyakrabban szociológiai, pszichológiai és menedzsment megközelítéssel találkozhatunk. Az eltérö tudományterületek eltérő definíciókat használnak kutatásuk alapjául.

A generáció definícióját a szakirodalom többféleképpen értelmezi, talán ez is az egyik oka az ellentétes véleményeknek és eredményeknek a témában. A kutatók az első utalást a generáció fogalmára az ókorból fennmaradt szövegekben találták. Az ókori egyiptomi írásokban és ábrázolásokban a generációs utalások a bonyolult rituálékhoz és rítusokhoz köthetők, ahogy az egyének beléptek saját életükbe, halálukba és túlvilági életükbe. Az ókori görögöknél pedig a saját történelmük kialakulásának fázisaihoz kötötték a generációkat, és azon fázisok jellemzőivel ruházták fel őket (aranykor - arany generáció, ezüstkor - ezüst generáció, bronzkor - bronz generáció és vaskor - vas generáció) (Joshi, 2011). Az ókori és modern generációértelmezés közti különbséget leginkább úgy lehet leírni, mint egyfajta különbséget a jelenség (generáció) létének célja között. Az ókori generáció meghatározás célja a világegyetem megértése a generációkon keresztül, míg a modern meghatározás az egyénre helyezi a hangsúlyt, és már maga a generációk jelenlétének hatását vizsgálja az egyénre. A modern definícióalkotásban és -értelmezésben szerepet játszik az iparosodás és az ez által előidézett gyors fejlödés. Innentől kezdve a generáció fogalmát nem ciklikusan értelmezzük, hanem lineáris fejlődési pályát bejáróként (Joshi, 2011; Twenge, 2000).

Az ókori és modern generáció fogalomalkotás között kronológiailag megjelenik a generáció premodern fogalma. Időben az ókor után és a XX. század előtt járunk. Ekkor a generáció fogalma a rokonsági kapcsolatokon keresztüli tulajdon-, szokás-, hagyomány- és értékátvételen alapult. A generációváltás egyfajta beavatási szertartásként müködött és többnyire közösségi esemény volt (Joshi, 2011).

A szakirodalomban a szerzők eltérően értelmezik és definiálják a generáció modern fogalmát. A szerzők egy része (Mannheim, 1952; Kupperschmidt, 2000; Arnett, 2000; Deal et al., 2010; Ward, 1974; Schuman - Scott, 1989) úgy látja, a generációk elsődleges összekötő jellemzője a kollektív öntudat. Mások az életkort, a kohorszokat és a korszakokat veszik alapul (Lyons - Kuron, 2014; Tolbize, 2008; Twenge, 2000; Inglehart, 1977). A definícióalkotáskor létezik ezeknek a megközelítéseknek az ötvözése (Kertzer, 1983; Khera - Malik, 2014; Joshi, 2011), illetve egyéb szempontok figyelembevétele is, amit a következőkben részletesebben megvizsgálunk.

\section{A kollektív öntudatra épülő definíció}

A kollektív öntudattal elsőként Karl Mannheim foglalkozott a generációk kapcsán, az ő hagyatéka a témában a mai napig elsődleges forrásként számon tartott, a modern generációfelfogás megalapozása. Mannheim (1952) úgy határozza meg a generáció fogalmát, mint „,az egy időszakban született egyének, akiknek azonos a ,lokációjuk” és világnézetük, ami föként azokra a történelmi eseményekre és jelenségekre épül, amit mindannyian átéltek a gyerekkori éveikben." Ehhez hasonló definíciót ad Kupperschmidt (2000) is: „Beazonositható csoport, melynek tagjai azonos születési időszakkal, korral, lokációval és jelentös életeseményekkel rendelkeznek a kritikus fejlödési éveikben.” Soulez (2011) szerint, ,ezeknek a közös eseményeknek az ereje kialakit minden generációban egy egyedülálló hiedelemrendszert és attitüdöt, ami irányítja a viselkedését”. Mannheim definíciójának két fontos eleme van: 
Az egyik az azonos lokáció. Azokat tekinti azonos generációhoz tartozóknak, akik földrajzi elhelyezkedésük alapján hasonló eseményeket éltek meg. Így tehát nem tekinti egy generációnak az „1800-as években Kínában és Németországban élő fiatalokat" (Mannheim, 1952). Viszont egy generációhoz sorolja azokat, akik iparvárosban nőttek fel, akár egymástól távol eső kontinenseken, miközben más generációhoz sorolja az azonos ország vidéki területein felnövő egyéneket, mivel úgy véli, egészen más impulzusok és élmények érték a két területet. Ez a fajta vidék-nagyváros elszakadás a mai társadalmakra is legalább annyira, ha nem még inkább igaz. Arnett (2000) kutatásában bemutatja, hogy az iparosodott országok nagyvárosainak társadalmi tendenciái (házasságkötés, gyerekvállalás ideje, felsőoktatásban részt vevők aránya stb.) azonos irányban és közel azonos mértékben együtt mozognak, egyre nagyobb szakadékot képezve ugyanezen országok vidéki részei és a nem iparosodott országok között, amik ilyen formán hasonló kategóriát alkotnak.

Hasonlóan kezeli a földrajzi lokációt Deal et al. (2010) cikkében, bemutatja, hogy az eltérő régiókban a születési év alapján azonos generációba tartozók mégis más generáció elnevezést kapnak, így például Izraelben, ahol az egyes generációk a háborúk alapján vannak elnevezve.

Mannheim definíciójának másik fontos eleme a gyerekkorban átélt történelmi események és jelenségek, és erre épülő világlátás. Mannheim (1952) szerint születésünk után ér minket egy „első benyomás”, majd ezt követi egy újabb, második benyomás, majd harmadik és így tovább. Ezek a benyomások gyerekkori tapasztalások és élmények, amik abban a sorrendben „rétegződnek” bennünk, ahogy értek minket. Különbséget tesz a gyerekkori tapasztalások és a későbbi, felnőttkori tapasztalások között, ahogy a legtöbb szerző teszi, mivel a gyermekkori szocializáció során ért hatások köztudottan meghatározóbbak a későbbi személyiséget és viselkedést illetően (Twenge, 2010; Ward, 1974).

Mannheim szerint a felnőttkori tapasztalatokat már csak az elsődleges rétegeken keresztül vagyunk képesek értelmezni, ezzel indokolja a generációk egységességét és egymástól való különbségét. Ezzel szemben Soulez (2011) vitatja ezt az elméletet, úgy véli, a családi minták erősebben hatnak az egyénre, mint a makrokörnyezet eseményei, illetve ezek az események véleménye szerint minden generációra (aki megéli az eseményt) egyenlően hatnak. Schuman - Scott (1989) a kollektív öntudat kifejezést kiegészíti egy ezáltal formálódó kollektív emlékezettel „az azonos generáció tagjai közös, mély tapasztalásokban részesülnek, aminek segitségével kialakitanak egy kollektiv emlékezetet".

Mannheim (1952) bevezeti a ,generációs egység” (,generation unit") fogalmát. Az ugyanazon generáció tagjai, akik a közös élet- és történelmi eseményekre eltérö módon reagálnak, eggyel szorosabb csoportot, a generációs egységet alkotják, ami Mannheim szerint egy jóval szorosabb kötelék. Kelan (2014) szerint a fiatal felnőttkorban ért kollektív tapasztalások a generációs egységek esetében jóval szorosabb köteléket eredményeznek az egységen belül, mint amit a biológiai jellemzők.

\section{Az életkorra, kohorszra és korszakokra épülő definíció}

Ellentétben Mannheimmel, aki a generációkat és azok hatásait főként társadalmi szinten vizsgálta és értelmezte, az életkorral és kohorsszal alkotott definíciók szerzői elsősorban a generációk egyéni viselkedésre és attitüdre gyakorolt hatását vizsgálják.

A modern menedzsmentirodalomban a leggyakrabban használt elv a generációk meghatározására az életkor alapján történő csoportosítás. A folyamat első lépéseként meghatároznak két határpontot, az éppen vizsgált generációk születési idejének kezdőpontját és végpontját, általában 15-20 évnyi időtávról beszélünk, majd a születési év kijelöli az egyének generációs hovatartozását. Ez a megközelítés annyiban támaszkodik a kollektív események által körülhatárolt generációmeghatározáshoz, hogy a határpontokat nagyobb eseményeknek megfelelöen alkotják meg (Lyons - Kuron, 2014). A szerzők egy része különbséget tesz generációkon belül első hullám, a generáció magjai (,core group”) és késői hullám között (Tolbize, 2008). Ezt a csoportosítást alapul véve, a szerzők nem tekintik homogénnek a generációkat, hanem az első hullámot még az előző generációk utolsó hullámával hasonlónak, míg a késői hullámot a következő generáció első hullámával hasonlónak tekintik (Twenge, 2000).

Kertzer (1983) megfogalmazza az életkorra, kohorszra és korszakokra épülő megközelítés kritikáját. A szerző szerint az életkor változásának, illetve a kohorsznak és a történelmi korszakoknak hatása nehezen kiszürhető, így a generációk meghatározásakor, jellemzőik felmérésekor sok esetben téves feltételezésekre juthatunk. A témában kutató szerzők nagy része egyetért ezzel a felvetéssel, és saját kutatásai korlátjaként jeleníti meg mindezt (Twenge, 2000; Deal et al., 2010; Arnett et al., 2013; Khera - Malik, 2014), azonban léteznek az elmúlt pár évtizedben longitudinális kutatást végző szerzők, akiknek pár generációt átölelö eredményei születtek a témában, így például Smola - Sutton (2002), Kowske (2010) és Twenge et al. (2004).

\section{Egyéb tényezőkre épülő definíciók}

Joshi (2010) véleménye szerint a generáció elnevezést nemcsak születési idő és kollektív öntudat által lehet behatárolni. Generációs fogalmakkal foglalkozó írásában (2011) felveti, hogy egy generációnak lehet tekinteni szervezeti szemszögből a közel egy időben a szervezetbe lépett egyéneket, függetlenül a koruktól és más tényezőktől. Úgy gondolja, hogy mivel azonos időszakban kerülnek a szervezet életébe és azonos tréningeken, orientációs programon vesznek részt, hasonló képük alakul ki a szervezetről, és ezáltal hasonló attitűdöt és kommunikációs stílust fognak felvenni.

Joshi (2010) emellett olyan generációmeghatározást is felkínál, ami a genealógiára, tehát a rokonsági kapcsolatokra, leszármazásra, családfa felépítésére épül. Az ókori hagyományátadó, tradicionális generációdefinícióhoz hasonlóan a rokonsági kapcsolatot alapul véve, az értékek és erőforrások átadását tekinti a generációk alapjának, ezt vezeti be szervezeti kontextusba, mégpedig azzal az analógiával, hogy akár az idősebbek, de valójában kortól 
függetlenül, a pozíciót éppen elhagyó egyének átadják azt a frissen érkező „generációnak”.

A cikkek, tanulmányok és könyvek tehát eltéröen közelítik meg a generáció definícióját, de többségében közös alapnak tekintik, hogy a generációk kohorszok, melynek tagjai hasonló életeseményeket éltek meg. A szakirodalmak eredményeinek bemutatásakor a közös definíciómetszetet vesszük alapul, ami az életkor, a kohorszok, befolyásolva mindezeket a megélt közös élményekkel.

\section{Generációk a munkaerőpiacon}

Jelenleg négy generáció van jelen a munkaerőpiacon. A négy generáció a Veteránok, a Baby Boomer-ek, az X generáció és az Y generáció. Ezen kívül még nincs a munkerőpiacon, illetve elenyésző mértékben a soron következő Z generáció, illetve az azt követő Alfa generáció. Ahogy már említettük, a generációk születési idejének, nevének meghatározása kultúránként eltérő. A szakirodalomban található források nagy része az USA-ból kerül ki, néhány európai és valamivel több ázsiai, illetve egy-két afrikai és ausztrál kutatás született, legalább is érhető el. Jelen cikk az általánosított, USA-ból érkező elnevezéseket használja, kiegészítve az említett régiók információival. Az egyes régiók esetében a generációk által behatárolt időszakok eltérnek, így a jelentős eltérések az 1. táblázatban megtekinthetők.

\section{A Baby Boomer-ek}

A Baby Boomer generáció megtapasztalta az előnyeit és hátrányait is a háborúnak és a civil jogi mozgalmaknak. Az USA-ban nagy hatással volt erre a generációra a vietnámi háború, a szexuális forradalom, Kennedy elnökgyilkosság és a hidegháború. Nukleáris családokban nőttek fel, ahol idealisztikus és optimista világképet mutattak számukra (Kupperschmidt, 2000). Legfőbb munkahelyi értékeik: egyenlőség, optimizmus, lojalitás, bevonódás, minden megkérdőjelezése, csapatszellem. Ellenáll a technológiának, de felismeri a fejlődés szükségességét, így lassan hozzászokik (Bokor, 2007).

\section{Az X generáció}

Az X generáció képviselőit gyakran úgy emlegetik, mint digitális bevándorlók (Tari, 2010). A generáció elnevezése Douglas Coupland „X generáció” címü könyve nyomán terjedt el. Hatással volt rájuk a nők munkába állása, már olyan családot tapasztaltak meg, ahol gyakran gyerekként magukról kellett gondoskodniuk (Soulez - Soulez, 2011). Magyarországon az X-es gyerekek, illetve fiatal felnőttek idejében jelent meg a kábeltévé, a személyi számítógép, a videójáték. Szélsőségesen élték meg a rendszerváltást, vagy profitáltak a változásból, ezzel megteremtve életük elindításához szükséges erőforrásokat, vagy a rendszerváltás

Az egyes régiókban a generációk által behatárolt időszakok

1. táblázat

\begin{tabular}{|c|c|c|c|c|c|}
\hline Generáció & Dél-Afrika & USA & Európa & Japán & Magyarország \\
\hline Veterán & $1930-1949$ & $1923-1942$ & $1918-1945$ & $1925-1945$ & $1928-1945$ \\
\hline Baby Boomer & $1950-1969$ & $1943-1962$ & $1946-1965$ & $1945-1965$ & $1946-1965$ \\
\hline X generáció & $1970-1989$ & $1963-1983$ & $1966-1984$ & $1966-1984$ & $1966-1979$ \\
\hline Y generáció & $1990-2000$ & $1984-2001$ & $1985-2001$ & $1986-2001$ & $1980-1995$ \\
\hline
\end{tabular}

Forrás: saját szerkesztés (Soulez, 2011; Arnett et al., 2013; Joshi, 2011; Twenge, 2000; Kupperschmidt, 2000; Deal et al., 2010; Schuman - Scott, 1989; Kelan, 2014; Khera - Malik, 2014; Lyons - Kuron, 2014; Smola - Sutton, 2002, Bokor, 2007, Tari, 2010)

A következökben bemutatjuk az egyes generációk általános jellemzőit. Főként azt a témát járjuk körbe, hogy mik a legfontosabb életesemények, amik hatással voltak adott generáció tagjaira.

\section{A Veteránok}

Más néven Tradicionalisták (Lester et al., 2012; Khera - Malik, 2014; Mencl - Lester, 2014), Néma generáció (Lester et al., 2012; Twenge, 2000; Schullery, 2013). Az életüket befolyásoló nagy események: a II. világháború, a világgazdasági válság, New Deal program. Főbb értékek, amit képviselnek a munkahelyen: szabályokhoz való ragaszkodás, konformitás, hozzájárulás a közösségi jóhoz, áldozathozatal, késleltetett jutalom, hatalom tisztelete, kötelességtudat, kemény munka, lojalitás, patriotizmus, türelem (Khera - Malik, 2014). Nem jártas a technológiában, a személyes megbeszélést preferálja az e-mail vagy a telefon helyett (Bokor, 2007). „,veszteseiként”, kevésbé sikeresen. A rendszerváltást követően a multinacionális cégek hazai elterjedésével hirtelen hatalmas igény keletkezett a vállalatok részéről szellemi munkát végzőkre, olyan fiatalokra, akik könnyen tanulnak, stabil munkahelyet szeretnének, gyorsan jó munkaerő válhat belölük. Ebben az időszakban került sok X generációs vezető pozícióba (Bokor, 2007). Főbb munkaértékeik: technológiaörült, független, egyensúlyra törekvő, szkeptikus, megbízható, magas munkaelvárások, magasan kvalifikált, szórakoztató dolgokra vágyik (Khera - Malik, 2014).

\section{Az Y generáció}

Más néven Millenium generáció (Twenge, 2010; Khera - Malik, 2014; Deal et al., 2010; Arnett et al., 2013), Én generáció (Twenge, 2010; Arnett et al., 2013), Következő generáció (Smola - Sutton, 2002), Nézz Rám generáció (Jensse et al., 2013). A rendkívül gyors technológiai fejlödés az Y generáció születését követően indult útnak, ami 
kéz a kézben járt a globalizációval. Ennek köszönhetően egy meglehetősen új világ nyílt meg mindenki számára. Nem csoda, hogy az egyik legnagyobb szakadék az X és az Y generáció között húzódik, hiszen merőben más élményei, igényei, lehetőségei támadtak az új generációnak, mint amit a X-esek fiatal felnőtt korukban megtapasztalhattak. Az Y generációt Youtube generációnak (Soulez, 2011) is becézik, mivel az ö idejükben már nem kellett elővenni a CD-lejátszót és -lemezt vagy a magnókazettát, bekapcsolni a rádiót, egész egyszerúen, bármit szerettek volna hallgatni, segítségükre volt egy online felület, ahol keresgélés nélkül, egy szemvillanás alatt szinte minden zeneszám elérhető.

Hatással volt rájuk az USA-ban a szeptember 11-i terrortámadás, az iskolai lövöldözések, a digitális média elterjedése, az AIDS és fiatal felnőttként a gazdasági válság (Khera - Malik, 2014). Magyarországon a rendszerváltás és a Disney-délután megszakítása Antall József halála miatt (a magyar Y-osok nagy részének mélyen emlékezetébe vésődött a pillanat, többen ezt emlegetik fel gyerekkoruk meghatározó politikai eseményeként, aminek hatására egy közösségi média oldal is született) (Bokor, 2007).

Főbb munkahelyi értékeik: magabiztosság, asszertivitás, diverzitás elfogadása, tolerancia, versenyszellem, praktikusság, spiritualitás, azonnal akarás, törekvés, technológiában jártasság (Twenge, 2010; Soulez, 2011).

\section{A generációs különbségek és hasonlóságok}

A szakirodalmi áttekintés során kirajzolódtak egymást átfedő területek, amikkel a szerzők leggyakrabban foglalkoznak kutatásaik során. Négy csoportot hoztam létre, amik lefedik a szakirodalom nagy részét. A szerzők többsége kutatása során magára a jelenségre, illetve az egyes generációk jellemzőinek bemutatására fókuszál. A négy témakör a következő: 1. Elégedettség a munkával, 2. Munkaetika, 3. Felelősségvállalás, 4. Munka-magánélet egyensúlya.

\section{Elégedettség a munkával és váltás}

Az Y generációval foglalkozó, empíria nélküli, anekdota jellegü cikkek túlnyomó része számol be arról a jelenségről, hogy az Y generáció tagjai „,nehezen motiválhatóak” (Woodward et al., 2015), nem elégedettek a munkájukkal, mivel folyamatosan újra, izgalmasabbra vágynak, amihez nagyobb felelősség párosul (Schullery, 2013). Mindemellett pedig nem értékelik a képzésükbe fektetett erőfeszítéseket, illetve azonnal váltanak, ha valamelyik részével nem elégedettek a munkának. Ward (1974) négy évtizeddel ezelőtt már írt a fogyasztói társadalomról és annak szocializációs hatásáról. Ennek tudható be a szerzők szerint az azonnali váltás jelensége. Ide sorolják egyes szerzők a kitartás hiányát, az azonnali visszajelzés és jutalom igényét is a generáció részéről (Twenge et al., 2004).

Az empirikus kutatások ebben a témakörben ellentmondásosak. Kowske et al. (2010) nagy mintán végzett kutatása szerint az Y generáció képviselői elégedettebbek munkájukkal, mint az idősebb generációk tagjai. Ezzel szemben Cennamo és Gardner (2008) keresztmetszeti vizsgálata során arra az eredményre jutott, hogy az Y generáció szignifikánsan könnyebben hagyja ott a munkahelyét, mint Baby Boomer vagy X generációs társai, viszont nem találtak különbséget a munkával való elégedettségben és az elkötelezettségben. Jelentős különbséget találtak azonban az X generációs munkavállalók elkötelezettségében, a többi generációhoz képest, de nem a szervezet felé, hanem a szakma felé, amit képviselnek.

Twenge (2010) kutatása szerint a szervezet elhagyása életkori sajátosság, nem pedig generációs kérdés, ő longitudinális kutatása során azt találta, hogy 24 év alatt az egyének nagyobb hajlandóságot mutatnak a munkahely elhagyására, míg 24 éves kor felett a munkavállalók 74\%a nyilatkozik úgy, hogy eltöltené az életének munkával töltött éveit a jelenlegi vállalatánál.

Deal et al. (2010) szerint a 2010-be fiatal pályakezdő Y generációsokra nagy hatással volt a gazdasági válság, mivel munkába lépésük, illetve egyetemi végzős éveik alatt tapasztalhatták meg azt, ami mély nyomot hagyott sokukban. A szerző szerint ez az esemény, bár mindenkire hat valamilyen módon, a munkahelyi biztonságot, a munkahelyhez kötődést csak az abban a pár évben munkaerőpiacra lépő egyének esetében befolyásolta. Ök tapasztalták meg a magas munkanélküliséget és a versengést a munkahelyekért, így jobban vigyáznak saját pozíciójukra és jobban is értékelik azt.

Soulez - Soulez (2011) franciaországi kutatása alapján a megkérdezett Y generációsok 14,23\%-a szeretne állandó pozíciót és garanciát arra, hogy évek múlva is meglesz az állása. A kutatásuk alapján a generáció 12,3\%-a maradna több évig ugyanazon a munkahelyen, vágyik az állandó pozícióra adott vállalatnál, és ez együtt járt a kutatásban az alacsonyabb végzettséggel és a szokványos munkaórák iránti vággyal.

Soulez és Soulez (2011) a 2. táblázatban látható négy csoportot különítette el az Y generáción belül, ahol úgy látta, a munkaértékek együtt mozognak, ezáltal csoportokat lehet létrehozni.

2. táblázat

\section{Az Y generáció négy csoportja}

\begin{tabular}{|c|c|c|}
\hline Megnevezés & $\%$ & Jellemzó \\
\hline $\begin{array}{l}\text { Biztonságke- } \\
\text { resők („,Secu- } \\
\text { rity seekers”) }\end{array}$ & 12,3 & $\begin{array}{l}\text { - szokványos munkaórák } \\
\text { - pozíció biztonsága } \\
\text { - alacsonyabb végzettség }\end{array}$ \\
\hline $\begin{array}{l}\text { Karrierorien- } \\
\text { táltak („Care- } \\
\text { er minded”) }\end{array}$ & 53,5 & $\begin{array}{l}\text { - vágynak egy magas presztízsü cégnél } \\
\text { való munkára } \\
\text { • ranglétrán lépkedés vágya } \\
\text { • magas fizetés }\end{array}$ \\
\hline $\begin{array}{l}\text { Egyensúlyke- } \\
\text { resők („Balan- } \\
\text { ce seekers”) }\end{array}$ & 28,6 & $\begin{array}{l}\text { - a munka minősége fontos } \\
\text { - munka-magánélet egyensúlya fontos } \\
\text { - nyugodt környezet, közel az } \\
\text { otthonhoz } \\
\text { - változatos feladatok }\end{array}$ \\
\hline $\begin{array}{l}\text { Lezserek } \\
\text { (,Easy } \\
\text { going”) }\end{array}$ & 5,6 & $\begin{array}{l}\text { - informális környezet } \\
\text { - alacsony profilú cégek } \\
\text { • nem vezetői pozíciók } \\
\text { - rutinfeladatok }\end{array}$ \\
\hline
\end{tabular}

Forrás: Soulez - Soulez (2011); saját szerkesztés 
Az elégedettséggel és váltással kapcsolatos kutatások nagy része nem emeli ki a vizsgált alanyok munkájának jellemzőit, sajátosságait, így az összehasonlítás és a következtetések levonása is megkérdőjelezhető.

\section{A munkaetika}

A munkaetika témaköréhez soroltam a munkamorált, a munka szerepét az egyén életében, munkaattitüdjét és a szabadidős tevékenységét (a szerzők a szabadidőt többnyire együtt kezelik a munkaetikával, és azt vizsgálják, hogy mennyire keveredik a munkavégzés a szabadidős tevékenységekkel, tehát mennyire viszik be a „szórakozást” a munkahelyre) (Twenge, 2010).

Smola és Sutton (2002) longitudinális kutatása alapján az Y generáció tagjai értenek egyet legnagyobb arányban azzal az állítással, hogy „otthagynám az állásom, ha sok pénzt örökölnék” és a legkevésbé azzal, hogy ,,a gazdag embereknek kötelességüknek kellene érezniük, hogy dolgozzanak, még akkor is, ha nincs rá szükségük."

Twenge (2010) kutatási eredménye szerint az Y generáció tagjai sokkal nagyobb százalékban vallották, hogy „ha elég pénzem lenne, nem dolgoznék többet.” Számos, általánosságra vonatkozó kérdések mentén mérték fel a szóban forgó kutatásban az alanyok attitüdjét a munka szerepével kapcsolatban. Fontos e kutatások esetében tisztázni, hogy az életkor nem lehet hatással a generációk közti különbségekre jelen két kutatás esetében, mert az egyéneket ugyanabban a korban kérdezték meg. Ezzel együtt az életkornak lehet olyan hatása az eredményre, hogy mivel fiatal felnőtteket kérdeztek meg, akik pályakezdőként szerepeltek a felmérésben, valószínúleg nem tudták reálisan mérlegelni, mit jelentenek az egy életre szóló kijelentések, ennek ellenére az a különbség nem vitatható, hogy ugyanabban az életkorban máshogy mérlegeltek a különböző generációk tagjai.

Deal et al. (2010) kutatása szerint az Y generáció tagjainak alacsonyabb a lexikális tudása ugyanabban az életkorban, a gimnázium végzős osztályában, mint a megelöző generációk esetében. Lester et al. (2012) tanulmányából az derül ki, hogy az Y generáció tagjai lényegesen többet dolgoznak (munkával töltött órák száma), mint az idősebb generációk, mégis a munkamorálra (fegyelmezett munkavégzés, kötelességtudat) alacsonyabb értékeket kaptak. Emiatt említik a szabadidős tevékenységek szerepét. Jenssen et al. (2014) eredményei alapján a fiatal generáció a magánéleti és szabadidős tevékenységeinek egy részét gyakran a munkaidejében végzi.

A kutatások túlnyomó többsége arra az eredményre jutott, hogy az Y generáció életében a munka sokkal kisebb szerepet kap, különösen figyelnek a munka-magánélet egyensúlyára, amire a későbbi pontban ki is térünk. Ennek ellenére a pénz fontossága nőtt a szemükben (Twenge - Kasser, 2013). Ennek magyarázatát Twenge és Kasser (2013) abban találja, hogy a materialista értékek meghatározóbbak lettek az Y generáció számára, mint a Veteránok, Baby Boomer-ek, vagy az X-esek esetében voltak. A szerzőpáros a materializmust a következőképp fogalmazza meg: ,Az abba vetett hit, hogy fontos azoknak a társadalmilag megerösitett céloknak az elérése, mint a pénzügyi siker, szép tulajdontárgyak birtoklása, megfelelö image kialakitása magunkról és magas státus" (Twenge - Kasser, 2013, p. 883.). A szerzők két okra vezetik vissza a materializmus növekedését: társadalmi instabilitás és társas minták. Az egyének, akik számára a materiális értékek különösen fontosak, számukra gyakran együtt jár egy magánéleti elégedetlenséggel, alacsony boldogságszinttel, magas szintü depresszióval és szorongással (Twenge Kasser, 2013). A materiális értékeket követő egyének életstílusa sokszor ökológiai szempontból megterhelő a Föld számára, és gyakori az egyfajta versengés és a másokkal szembeni előítéletek alkotása. A kutatás eredményei továbbá azt mutatták, hogy azoknak az egyéneknek az esetében, akiknek családjában valamilyen bizonytalanság volt jelen (elvált szülők, betegség, szegénység), vagy a társai kiközösítették, esetleg valamiért különösen nehéznek élte meg a gyerekkorát, azoknál az egyéneknél jelennek meg a materialista értékek.

A kutatás további kérdése, hogy amennyiben a materialista értékek fontosabbak lettek, akkor az egyének munkának szentelt ideje és fontossága ezzel együtt miért csökkent (Twenge - Kasser, 2013). Erre válaszként nyúl vissza Twenge 2004-ben készült kutatásához, amelyben a generációkon keresztüli nárcizmus jelenségének számottevő növekedése figyelhető meg. Twenge álláspontja szerint a nárcisztikus ,én megérdemlem, nem kell érte tennem” gondolatvilág és a könnyü celebség, a pénzügyi szektor terjeszkedése, a banki környezet kevésbé szabályozottsága és a gyors meggazdagodás kommunikálása a médián keresztül választ ad a kérdésre (Twenge - Kasser, 2013).

\section{A Felelősségvállalás}

A felelősségvállalás kapcsán egyrészt azt vizsgálják a szerzők, hogy az Y generáció tagjai mennyire keresik, vágynak a felelösségteljes munkakörökre, idősebb társaikhoz képest (Soulez - Soulez, 2011). Másrészt, azt is kutatják, hogy az Y generáció tagjainak egyéni felelösségvállalása mennyire magas. Mennyiben tudják be a körülöttük történt dolgokat saját maguknak, mennyiben a környezetnek (Twenge et al., 2004), másképp megfogalmazva, mit gondolnak róla, a kontroll kinek a kezében van, többnyire a sajátjukban vagy a külvilágéban?

Twenge et al. (2004) bevezeti a ,locus of control”a kontroll helye - fogalmát, és bemutatja, hogy kétféle típusú ember létezik ebből a szempontból, aki többnyire belső kontrollt érez, és aki többnyire külsőt. A kutatást 1960-ig vezeti vissza, és vizsgál olyan értékeket is, mint individualizmus és kollektivizmus. Vizsgálata szerint az individualizmus az egyéneknél magasabb szintü az Y generáció esetében, mint a többi generáció esetén volt ugyanabban az életévükben - az USA-ban - , aminek némiképp ellentmond, hogy a kontroll sokkal inkább külsővé vált (Twenge et al., 2004). Ezzel egyidőben a felelősségvállalás a saját tetteikkel kapcsolatban csökken. A szerzők ezzel a jelenséggel magyarázzák az iskolákban használt tanulási rendellenesség egyre nagyobb fokát, azt a jelenséget, hogy az USA-ban a vállalatokat egyénileg be lehet perelni azért, mert a kávéjuk túl forró (ahogy a Starbucks esetén meg is történt), illetve a bírósági tár- 
gyalásokon lehet bizonyos fokú büncselekmények esetében arra hivatkozni, hogy nehéz gyerekkorunk volt. Lester et al. (2012) szerint ez az attitüd mindig is valamilyen szinten jelen volt az emberek életében, de az Y generációt jobban jellemzi, miközben nagy magabiztossága és pozitív önképe eredményeképp a sikerei kulcsát magában látja. Twenge et al. (2004) kutatása arra is rámutat, hogy az Y generáció tagjai sokkal nagyobb mértékben maradnak távol a választásokkor, mint az előző generációk, ezt összefüggésbe hozza a felelősség kívülre helyezésével. Soulez - Soulez kutatása szerint az Y generáció 53,5\%-a keresi kifejezetten a felelősségteljes pozíciókat (Soulez - Soulez, 2011).

\section{A munka-magánélet egyensúlya}

A kutatások többsége szerint az Y generáció számára jóval fontosabb a munka és a magánélet egyensúlya, mint az X generáció számára, a Baby Boomer és a Veterán generáció számára hasonlóan fontos a munka. Így ebben a tekintetben az $\mathrm{X}$ generáció tér el a többi generációtól (Soulez - Soulez, 2011). Soulez és Soulez (2011) kutatási eredménye szerint az Y generáció 28,6\%-a kifejezetten olyan munkahelyet keres, ahol a munka és a magánélet egyensúlya megteremthetö.

Cennamo és Gardner (2008) kutatása alapján az Y generáció a munkában elérhető szabadsággal köti össze a munka-magánélet egyensúlyát, és megállapításuk szerint az Y generáció magas igénye az egyensúlyra szignifikánsan magasabb, mint az idősebb generációké.

Bokor Attila (2007) magyar Y generációsokon végzett kutatása alapján a pályakezdők azzal a gondolattal tekintenek a munkájukra és magánéletükre, illetve ezeknek egyensúlyára, hogy az első nagyjából tíz évében az egyéneknek túlórát és nagy erőfeszítést kell tenniük a munkájukba annak érdekében, hogy később, amikor már családjuk van, learathassák annak gyümölcsét. A megkérdezettek nagy többsége azt nyilatkozta, hogy szeretne családot, és kifejezetten fontos számukra, de tudják, hogy áldozatot kell hozniuk annak érdekében, hogy később az egyensúly megvalósulhasson. Magyarországon a megkérdezettek tradicionálisnak mondható családmodellt képzelnek el, ahol a pénzkeresés elsősorban a férfiak dolga, a megkérdezettek egy része azt válaszolta, hogy fontos neki, hogy a nő is dolgozzon (akár nőt, akár férfit kérdeztek meg), de a férfiak kevésbé számítanak a női pénzkeresetre (Bokor, 2007).

Jelen cikk célja a szakirodalom áttekintése a generáció témájában. Alaposan áttekintettük a generáció fogalmát, definícióját, annak változását az idők során, meglévő értelmezéseit. Ezután az egyes generációk általános jellemzőit vettük sorra. Jelen cikk nem foglalkozik a generációs munkahelyi jellemzőkről készült kutatások teljes körü bemutatásával, sokkal inkább egy általános képet ad a téma leggyakoribb kutatási területeiről és eredményeiről. A részletes következtetések, különbségek bemutatása egy következő cikk témája lehet.

\section{Konklúzió}

Jelen cikk célja a nemzetközi szakirodalom feltérképezése a generációk témakörében, a generáció fogalmának kialakulásától kezdve, a jelenleg használatban lévő definíciókon át a konkrét generációs különbségekig. A téma mélyebb megértéséhez fontos, hogy az alapvető fogalmakat és definíciókat széleskörüen megismerjük. A generáció definíciójáról különböző kutatói megközelítéseket mutattunk be. A nemzetközi és magyar kutatások alapján feltérképeztük a jelenleg munkaerőpiacon lévő generációk (Baby boomer, X generáció, Y generáció, Z generáció) általános és munkahelyi jellemzőit. A munkahelyi jellemzőket vizsgálva négy nagyobb vizsgálati területet különítettünk el: szervezeti elégedettség, munkaetika, felelősségvállalás és munka-magánélet egyensúlya.

\section{További kutatási lehetőségek}

Az áttekintett szakirodalom alapján kirajzolódnak további lehetséges kutatási területek. A generációs különbségek témakörben számos kvantitatív kutatás készül, azonban kvalitatív, az összefüggések mélyebb megértését célzó kutatás nem jellemző. A generációs különbségekből fakadó konfliktusok, lehetséges kezelési módjuk vizsgálata leginkább az Egyesült Államokban elterjedt, arányaiban kevés európai, még kevesebb hazai tudományos kutatás születik a témában. Érdemes lenne különbözö, generációkon belüli csoportokat, szubkultúrákat vizsgálni, kevésbé homogén csoportként kezelve ezeket, ezáltal árnyaltabb képet kapva a generációk egészéről. Arnett et al. (2013) vizsgálja a fiatalabb generációk erősségeit, hozzáadott értékét a szervezeti életben, azonban az erősségek keresése, a lehetséges előnyök kiemelése meglehetősen ritka.

\section{Felhasznált irodalom}

Arnett, J. J. (2000): Emerging adulthood: a theory of development from the late teens through the twenties. American Psychologist,Vol.55. no. 5., p. 469-480.

Arnett, J. J. - Trzesniewski, K. H. - Donellan, M. B. (2013): The dangers of generational myth-making. Emerging Adulthood, p.17-20.

Barsh, J. - Brown, L. - Kian, K. (2016): Millennials: burden, blessing or both?

Beechler, S. - Woodward, I. C. (2009): The global „war for talent". Journal of International Management

Bokor Attila (2007): Létezik-e itthon Y-Generáció? Vezetéstudomány, 2. szám, p. 2-21.

Cennamo, L. - Gardner, D. (2008): Generational differences in work values, outcomes and person-organisation values fit. Journal of Managerial Psychology, Vol. 23., No. 8., p. 891-906.

Davis, J. A. (2009): Did growing up in the 1960s leaves a permanent mark on attitudes and values? Evidence from the General Social Survey. The Public Opinion Quarterly

Deal, J. J. (2007): Retiring the generation gap: how employees young and old can gind common ground? 
Deloitte Touche Tohmatsu Limited (2017): The 2017 Deloitte millennial survey. apprehensive millennials: seek in stability and opportunities in an uncertain world.

Ernst and Young Global (2015): What if the next big diruptor isn't a what but a who? Gen $\mathrm{Z}$ is connected, informed and ready for business.

Ferincz Adrienn - Szabó Zsolt Roland (2012): A ,Z generáció" hatása a munkáltató szervezetekre. in: Innováció vezetői szemmel. Budapest: Aula Kiadó, p.185192.

Fogg, P. (2009): When generations collide. Education Digest: Essential Readings Condensed for Quick Review, p. 25-30.

Glass, A. (2007): Understanding generational differences for competitive success. Industrial and Commercial Training, p. 98-103.

Inglehart, $R$. (1977): The silent revolution: changing values and political styles among western publics. Princeton, NJ: Princeton University Press

Jenkins, J. (2007): Leading the four generations at work Jenssen, B. P. - Gray, N. J. - Harvey, K. - DiClemente, R. J. - Klein, J. D. (2014): Language and love: generation y comes of age online. Thousand Oaks: SAGE Open

Joshi, A. - Dencker, J. C. - Franz, G. - Martocchio, J. J. (2010): Unpacking the generational identities in organizations. Academy of Management Review, Vol. 35. no. 3., p. 392-414.

Joshi, A. - Dencker, J. C. - Franz, G. (2011): Generations in organizations. Research in Organizational Behavior, No. 31., p. 177-205.

Kelan, E. K. (2014): Organizing generations: What can sociology offer to the understanding of generations at work? Sociology Compass, Vol. 8., p. 20-30.

Kertzer, D. I. (1983): Generation as a sociological problem. Annual Review of Sociology, No. 9., p. 125-149.

Khera, S. N. - Malik, S. (2014): Conceptualizing and measuring life priorities of generation $\mathrm{y}$ : evidences from indian context. Industrial and Commercial Training, Vol. 42. No. 2., p. 80-86.

Kupperchmidts, B. R. (2000): Multingenerational employees: strategies for effective management. The Health Care Manager

Lancaster, l. - Stillman, D. (2002): When generations collide: who they are: why they clash: how to solve the generational puzzle at work. London: HarperCollins Publisher Inc.

Lester, S. W. - Standifer, R. L. - Schultz, N. J. - Windsor, J. M. (2012): Actual versus perceived generational differences at work: an empirical examination. Journal of Leadership - Organizational Studies, p. 341354.

LeVasseur, S. A. - Wang, C. H. - Mathews, B. - Boland, $M$. (2009): Generational differences in registered nurse turnover. Policy, Politics - Nursing Practice, p. 212-223.

Lyons, S. - Kuron, L. (2014): Generational differences in the workplace: a review of the evidence and direc- tions for future research. Journal of Organizational Behavior, p. 139-157.

Macky, K. - Garner, D. - Forsyth, S. (2008): Generational differences at work: introduction and overview. Journal of Managerial Psychology. Vol. 23. No. 8., p. 857-861.

Mannheim, K. (1952): The sociological problem of generations: essays on the sociology of knowledge. London: RKP

Mencl, J. -Lester, S. W. (2014): More alike than different: what generations value and how the values affect employee workplace perceptions. Journal of Leadership and Organizational Studies. Vol. 21., p. 257-272. $P w C$ (2013): PwC's next gen: a global generational study. Qenani-Petrela, E. - Schlosser, J. - Pompa, R. (2007): Satisfied employees are worth their weight in gold: what motivates generation y? Journal of Food Distribution Research, p. 112-119.

Roberson, $Q$. (2012): The Oxford handbook of diversity and work. Oxford: Oxford University Press

Salt, B. (2007): Beyond the baby boomers: the rise of generation y. KPMG International

Schullery, N. M. (2013): Workplace engagement and generational differences in values. Business Communication Quarterly, p. 252-265.

Schuman, H. - Scott, J. (1989): Generations and collective memories. American Sociological Review, p. 359-381.

Smola, K. W. - Sutton, C. D. (2002): Generational differences: revisiting generational work values for the new millennium. Journal of Organizational Behavior, Vol. 3. No. 4., p. 363-382.

Soós J. K. (2008): Generációk találkozása: értékrendek ütközése vagy hatékony együttmüködés? Munkapszichológia, 52. évfolyam, 1. szám, p. 29-34.

Soulez, S. - Soulez, C. G. (2011): Recruitment marketing and generational segmentation: a critical analysis based on a sub-segment of generation y. Recherche et Application en Marketing, Vol. 26. No. 1., p. 39-55.

Tari, A. (2010): Y generáció. Budapest: Jaffa Kiadó

Taródy D. (2012): A „Z generáció” vezetése. in: Innováció vezetői szemmel. Budapest: Aula Kiadó, p.193216.

Tolbize, A. (2008): Generational differences in the workplace. Research and Training Center on Community Living

Twenge, J. M. - Campbell, S. M. - Hoffman, B. J. - Lance, C. E. (2010): Generational differences in work values: leisure and extrinsic values increasing, social and intrinsic values decreasing. Journal of Management, Vol. 36. No. 5., p. 1117-1142.

Twenge, J. M. - Kasser, T. (2013): Generational changes in materialism and work centrality, 1976-2007: associations with temporal changes in societal insecurity and materialistic role modeling. Personality and Social Psychology Bulletin, p. 883-897.

Twenge, J. M. - Zhang, L. - Im, C. (2004): It's beyond my control: a cross-temporal meta-analysis of increasing externality in locus of control, 1960-2002. Persona- 
lity and Social Psychology Review, Vol. 8. No. 3., p. 308-319.

Twenge, J. M. (2000): The age of anxiety?: birth cohort change in anxiety and neuroticism, 1952-1993.

Twenge, J. M. (2010): A review of the empirical evidence on generational differences in work attitudes. Journal of Business Psychology, p. 201-210.

Twenge, J. M. - Campbell, W. K. (2010): The narcissism epidemic. New York: FreePress

Twenge, J. M. (2001): Birth cohort changes in extraversion: a cross-temporal meta-analysis, 1966-1993. Personality and Individual Differences. p. 735-748.
Van der Walt, F. - Jonck, P. - Sobayen, N. C. (2016): Work ethics of different generational cohort in South Africa. African Journal of Business Ethics, Vol 10. No. 1.

Ward, S. (1974): Consumer socialization. Journal of Consumer Research, Vol. 1. No. 2., p. 1-14.

Woodward, I. C. - Vongswadi, P. -More, E. A. (2015): Generational diversity at work: a systematic review of the research. Working Paper Series. INSEAD Business School

Zubány, E. (2008): Éljünk a sokszínüséggel! Munkapszichológia, 52. évfolyam 1. szám, p. 35-38. 